\title{
Türkçe belagat semantiğinde cümle bağlama, ayırma, birleştirme
}

\section{Meriç GÜVEN1}

APA: Güven, M. (2020). Türkçe belagat semantiğinde cümle bağlama, ayırma, birleştirme. RumeliDE Dil ve Edebiyat Araşttrmaları Dergisi, (20), 77-XX. DOI: 10.2900o/rumelide.791095.

\section{$\ddot{\mathbf{O} z}$}

Duygu ve düşüncelerin sade dille ve manası açık şekilde ifade edilmesinin esası belagat; belagatin şartı cümlelerin "bağlama”, "ayırma”, "birleştirme” yoluyla tertip ve tanzimidir. "İyi ve Doğru Yazma Usulleri” ile ilgili bu husus, belagat semantiğinde söz ve üslup güzelliğini ortaya koyan ve anlamı belirleyen bir konudur. Bu konu cümlelerin birbirleriyle mutabakatı gözetilerek ve vasıl (cümleleri ve bağlacı ile bağlama), fasıl (cümleleri ve bağlacı ile bağlamama) ve hem vasıl hem fasıl (cümleleri ve bağlacı ile bağlama, ayırma, birleştirme) kurallarına uyularak gerçekleştirilir. Bu gerçekleştirme hâlin icabına ve gereğine uygun düşen ve ögeler arasında intikal sağlayan bağlı ve ardışı cümlelerle; her biri kendi içinde bütünlük arz eden birbirinden bağımsız ve müstakil, fakat anlamca birbiri ile ilgili cümlelerle ve hem bağımsız ve müstakil ve hem birbirine bağlı ve zincirlemeli (müselsel) cümlelerle temerküz ve tekasüf eder (ortaya çıkar ve yoğunlaşır). Türkçe cümlelerde, bağlama işlevi gören "ve" bağlama edatı, bağlama edatı "ve”ye denk ve eşlenik işlev gören “, “ ve “ ;”, kabilinden bağlama işaretleri, bağ-fiil eki (y)Xp ve ayırma işareti nokta “.” bu bağlama, ayırma ve birleştirme işlemlerini gerçekleştiren figüratif “işleç”ler olarak kullanılır. Bağlayıcı ve ayırıcı unsurların yerinde ve doğru kullanılmasıyla söz ve ibareler ve cümleler arasında anlamlı birliktelikler, cümlelere sağlamlık ve ebedilik kazandıran ahenkli ve armonili dizimlikler oluşur. Aynı şekilde bağlayıcı ve ayırıcı unsurların yanlış kullanılmasıyla söz ve ibareler ve cümleler arasında uyumsuz ve uygunsuz yapılar, anlamı tamamlanmamış veya yanlış tanımlanmış cümleler ve cümleden büyük dil birlikleri ortaya çıkar.

Anahtar kelimeler: Belagat, cümle, bağlama, ayırma, birleştirme

\section{Sentence connecting, separation and merging" in Turkish Eloquence semantics}

\begin{abstract}
The basis of expressing emotions and thoughts in plain language with a clear meaning is the basis of eloquence, and the condition of eloquence is the arrangement and preparation of sentences by "connecting", "separation", and "merging". This issue, which is related with "Good and Correct Writing Methods", is performed by considering the agreement of sentences with each other as the subject revealing and determining the beauty of words and style in the narration in eloquence semantics-, and applying the rules of Vasıl (connecting sentences with "and" conjunction), Fasl (not connecting sentences with "and" conjunction), and both applying the Vasl and Fasl rules together (connecting, separating and merging sentences with "and" conjunction) by considering the agreement of sentences with each other. This realization occurs and intensifies in the form of consecutive sentences that are in accordance with the requirement of the context and that provide transfer between the elements with independent and separate, but integrated and relevant sentences, by using independent, separate and interrelated (sequential) sentences. In Turkish sentences, the
\end{abstract}

1 Doç. Dr. Uşak Üniversitesi, Fen Edebiyat Fakültesi, Türk Dili ve Edebiyatı Bölümü (Uşak, Türkiye) meric.guven@usak.edu.tr, ORCID ID: 00oo-0003-2533-5272 [Makale kayit tarihi: 12.06.2020-kabul tarihi: 20.09.2020; DOI: $10.29000 /$ rumelide.791095] 
conjunction-preposition "and”, and the conjunction signs “,” and “;”, which conjugate and are equal to conjunction "and", the gerund suffix (y)Xp and the separation sign period "." are all used as figurative "operators", which perform this Connecting, Separation and Merging process. By using the conjunctions and separating elements together in an accurate and timely manner, meaningful cohesion occurs between words, phrases and sentences together with consistent and harmonious sequences that give sentences strength and eternity. Similarly, with the misuse of the conjunctions and separating elements, incompatible and inappropriate structures appear between words, phrases and sentences together with incomplete or misidentified structures and supra-sentential language units (syntactic components).

Keywords: Eloquence, sentence, connection, separation, combining

\section{Giriş}

Cümle bağlama, ayırma ve birleştirme "belagat semantiği"nde (meani) yazı yazma ile ilgili icad (var etme) ve ibda (oluşturma), "nahiv ameli nazariyesi (etkinlik kuramı)"nde ittisak (toplama-dizileme) ile ilgili düzenleme ameliyesidir. Bu ameliyeye göre icad, zihinde yeni bir mevzu yaratma ve mevzuyu işleyecek fikri var etme; ibda bu mevzuyu işleyecek fikri geliştirerek yeni ve güzel, doğru ve sağlam cümleler meydana getirme; ittisak da doğru ve sağlam olan bu cümleleri düşüncenin akışına uygun sıralama ve bağlamadır (Güneş, 1999: 50). Bedii ve estetiki kıymet ve ölçüt taşıyan ve ibarenin (düşünce anlatan ve bir ya da birkaç tümceden oluşan söz) nerede başlayıp nerede biteceğini ve bağlayıcıların ibareler arasında nasıl kullanılacağını içeren bu husus, belagat kitaplarında medeniyetin kabul ettiği yüksek bedayiden, icat edilmiş güzel şeylerden bahseden bir sanat olarak görülmüsş; cümlelerin buluş, seçiliş ve sıralanış (biçem) maksadına bağlı olarak ele alınmış ve işlenmiş bir konudur (Sami, 1887: 3).

İfadenin tertip ve tanzimini kapsayan ve yönetme tümleyenleri içeren bu ameliyede amaç, sözün estetiki bir konuma getirilmesi ve cümlelerin tarz ve yöntem yönünden belagatin kurallarnna göre müştereken ve müteselsilen (arada hiçbir açıklk bırakmadan) düzenlenmesidir. Bu ameliyenin, asıl malzemesinin dil olması ve sözün doğru, güzel ve yerinde söylenmesine teşmil olması bakımlardan belirli noktalarda dilbilimle ve göstergebilimle kesiştiği ve kimi ortaklıklar gösterdiği söylenebilir (Dağ \& Gümüş 2018: 651). Konu ve yöntem olarak lafızlara değinilmesi, cümlelerin kapsamlı ve kiyaslı biçimde değerlendirilmesi ve Arap gramerini etkileyen bir konfigürasyon içinde düzenlenmesi bakımlarından Aristo mantığına dayandırılabilir. Aynı şekilde fiillerin üç zaman ve kelimelerin üç kategori halinde incelenmesi ve cümlelerin irab harekeleri (kelimelerin cümledeki konumları) yönüyle değerlendirilmesi bakımından nahiv (Ülgen, 2015: 1286); dilin dizge olarak değerlendirilmesi, dil-söz ayrımı ve nedensizlik ilkesi bakımından belagat (fesahat, meani ve beyan dalları) ile ilişkilendirilebilir (Yılmaz Orak, 2013: 337-341). Bütün bu yönleriyle Doğu literatüründe nahiv ve belagat, Batı literatüründe dil bilim ve retoriği ilgilendiren bu ameliye, sözün tertip ve tanzimini, kullanılma yerini esas alır, bağımsız sözlük birim (lexem) ve bağımlı- bağımsız biçimbirim (morphem)'lerin oluşturduğu cümle ve cümleden büyük dil birliklerinin birbiriyle ilgili ve ilişkili hale getirilmesini ve bir nizam dahilinde birbirine bağlanmasını ya da birbirinden ayrılmasını, böylece bütün fikrin ortaya çıkarılmasını gözetir.

Konuşan veya yazan kimse bu ameliyede, yaratılış hallerine bağlı olarak ilk önce kalbine gelen manaları fikir kurma (tahayyül), sonra zihinde şekillendirme (tasavvur) daha sonra akıl erdirme (taakkul) ile düşünme süzgecinden geçirir ve somut gerçekliklerle derin yapıdan yüzey yapıya çıarır (Ertuğrul, 2015: 157). Bu süreçte cümle, anlam ve işlev boyutu ile sınırlı kalmak ve ancak daha üst birimlere olanak vermek üzere anlatımın temel kalıbı olarak düşüncenin gerçekleşmesinde ve zenginleşmesinde 
belirleyici rol oynar; “anlam halkaları"nın oluşmasında ve mutlak ve bütün fikrin ortaya çımasında anlamsal ve işlevsel bir vazife görür.

“Anlam halkaları”, anlam açısından ortak bir paydada birleşen kelimelerin sözlüksel boyuttaki bağıntısal ilişkilerine ve anlamsal, kavramsal ve sözlüksel alanlardaki kullanılışlarına bağlı olarak "anlam birimcik (sem)" ve "anlam birimcik demeti (semem)"lerden oluşur. Bu oluşumda bağlayıcılar, kendisine bağlanılan önceki ve bağlanan sonraki ögeler arasında ana cümlenin sınırları içerisinde kalan ve ana cümle ile tedrici dokanak ilişkisi, fakat aynı benzer özellikleri gösteren "anklav"lı yapıların yer aldı̆̆ı "anlam halkaları”nı birleştirir. Bağlayıcılar bu meyanda, yatay düzlemde vasıl ve fasıl yaparak dil birliklerini kendisinden önce gelen, kendisiyle birlikte olan ve kendisinden sonra gelen unsurlara bağlar; belirsiz (müphem) ve ayrıntısız (mücmel) olanı belirli (mübeyyen) ve ayrıntılı (mufassal) hale getirirler. Dil ve ifadede birbirlerine uygun, birbirileriyle uyumlu cümleler kurar ve cümleler arasında koşut ve mütevazi olmayı gerçekleştirerek sözü bölümlere ve kısımlara ayırır, düşüncenin doğruluğunu ve anlama uygunluğunu ortaya koyarlar.

Bu itibarla işlev ve önemine istinaden belagat ilminin hazırlayıcısı Arap edip ve düşünürü Câhiz, Kitâbül-Beyân et-Tebyîn adlı eserinde belagati vasıl ve fasıl yapılacak yerleri bilmekten ibaret bir bilim diye saymış ve belagatin ölçüsü olarak birbirini izleyen cümlelerin doğru ve uyumlu biçimde tertip ve tanzim edilmesi olduğunu söylemiştir (Durmuş, 2012: 537). Tanzimat edibi Ahmet Cevdet Paşa da Belâgat-ı Osmâniyyede kavâ'id-i sarfiyye ve nahviyyesini cem ederek dil bilgisi gibi bir fen oluşturan ve bu hal üzere tederrüs ve ta'allüm edenlerin Osmanlı lisanında doğruca söyleyip yazmağa muktedir olacaklarını; ancak fasihâne ve belîgâne meram ifade edebilmek için beagat ilmini bilmek lâzım geldiğini dile getirmiş (Karabey \& Atalay, 1999:2) iyi, doğru ve güzel yazmanın ancak belagatle sağlanacağını dile getirmiştir.

Belagi- retorik kabul ve estetiki stilistikle ilgili bu ve benzeri yaklaşımlara göre dillerin güzelliği cümlelerin beliğ dil mantığı, metin tutarlılığı ve anlamsal bağlantılar yerdeşliği (izotopi)nde olması; fasihliği, cümlelerin tenafürden (yapı ve anlamca uyumsuzluktan) uzak, fasıl ve vasılı doğru yapılmış bir düzenekte kullanılması ile sağlanır. Bu itibarla dillerin söyleyiş güzelliği ve ifade kudreti kazanması, sanat ve edebiyat tarihlerinin ilk devrelerinden itibaren aşama aşama ve belli bir düzende olmuş ve diller ancak asırlar süren bir zaman içinde işlenerek ve dil kategorileri arasındaki ulam-bağıntı, nicelik-nitelik ilişkilerini düzenleyerek millî lisan hüviyeti kazanabilmişlerdir.

Asırlara ve coğrafyalara hükmeden Türkçe ise bir yazı dili olarak müstakil devletler kurduğu ülkelerde böyle bir hazırlı devresi geçirmiş ve tarihe, Orhun Abideleri gibi olgun bir eserle ve bir kültür ve tefekkür dili olarak girmiştir. Kitabelerdeki anafikir ve düşüncenin bütünleşik dile getirilmesi ve içeriğinin cümlelerle değil, grup cümlelerle açıllanması (Stebleva, 1965: 79) Türklerde yazılı dilin başlangıçtan itibaren giderek daha da zenginleşen ve derinlik kazanan bir gelişim gösterdiğini ortaya koyar. Bununla birlikte Türklerde iyi, doğru ve güzel söz söyleme ve yazma (belagat) çalışmaları birbirine bağlı bilgi ve öğretilerden oluşan bir düzen içinde ancak Osmanlı döneminde ve Arap dilinin etkisinde telif ve tercüme eserlerle başlamıştır. Türklerin İslamiyetin kabulünden sonra Osmanlı nahiv ve belagatinın oluşma ve yerleşme (teessüs ve takarrürü) devrinde Arapların ilim ve ulema erbabını, şeri ilimleri tahsil için inşasını (nesrini-düz yazısını) kabul etmeleri ve bu tarz üzerine yazmaları ile başlayan çalışmalar, Arapça asıllarından yararlanılarak yapılmış ve Sekkâkî’nin Miftâhul Ulum, Sadeddin Teftâzâni’nin Mutevvel ve Kazvînînnin Telhîsü'l-Miftâh eserleri ve bu eserlerin Hasan Çelebi ve Molla Hüsrev tarafından yapılan tercüme, şerh ve haşiyeleri (Yetiş, 1992: 384) ile sanatının zirvesine çıkmıştır. 
Tanzimat döneminde Batılı eğitim veren okulların açılmasıyla doğru ve güzel yazma ve söyleme (fesahat ve belagat) konuları modern dil bilim yöntemleri ile işlenmeye ve eski belagat kitaplarındaki anlayış ve yaklaşımlar yanında Batılı retorik kitaplarındaki anlayışlar da öğretilmeye ve uygulanmaya başlanmıştır. Dönemin fesahat ve belagatçileri bu çerçevede Klasik Doğu dil eğitimindeki nahiv ve belagat ve Batı dil eğitimindeki dil bilim ve retorikle ilgili konuları sentezci bir yaklaşımla ele almış, iyi ve doğru yazma usullerine uygun ve içerikle uyumlu eserlerle anlatmışlardır.

Bu dönemde Batı’yı yerinde ve merkezinde tanımış dil ve tarih üstadı Süleyman Paşa Mebani'l-İnşa, Batıdaki eğitim modellerine vakıf ve yazı alanında mahir Münif Paşa İlmi Belagat-La Rhetorique, Ceridei Havadis yazarı ve divan şairi Mehmet Nüzhet Muğni'l-küttâb, İlk çağdaş Türk eğitim bilimcisi ve Batılı tarz nahiv yazarı Selim Sâbit Miyârü’l-Kelam eseri ile Batı retoriğini, Türk edebiyatı ve belagati nazariyesine uyarlamış ve uygulamış önemli belagat yazarlarıdır (Yetiş, 1992: 3-31). Bunun yanında Batı literatüründeki retorik sınıflandırmasını esas alarak eserinde psikolojik unsurlara yer veren ve yeni bir üslup anlayışı yaratarak ve güzellik konusunu eleştirel işleyerek Talimi Edebiyat'ı yazan Recaizade Mahmut Ekrem; Türkçe tarifler yaparak ve Arap belagatini Türkçe'ye uyarlayarak tenkitli belagat kitabı Sefinei Belagat'ı yazan Abdurrahman Süreyya; Türk edebiyatının klasik dönemi kadar modern dönemi ile ilgili bilgilere yer vererek edebiyat tarihi, eleştirisi, kuramı ve terminolojisinde kıymetli eser IstılahatI Edebiyye'yi yazan Muallim Naci; Osmanlı edebiyatı derslerinden müteşekkil Türk dilinin kurallarına göre hazırlanmış Tedrisat- Edebiyye'yi yazan Abdurrahman Fehmi ve Arap geleneğinden gelen "Arapça örnek verme alışkanlığını ve temayülü"nü kırarak Türkçe örneklerle eğitimlik belagat kitabı Belagat-ı Osmaniyye'yi yazan Ahmet Cevdet Paşa devrin doğru ve güzel yazma anlayışına yön veren önemli belagat (meani) yazarları olmuştur (Yetiş, 1996: 3-31).

Tanzimat dönemi yazarları, devrin üslubunu etkileyen ve yönlendiren bu ve benzeri eserler vasıtasıyla, cümleleri ve cümleden büyük dil birliklerini işleyerek düşüncenin dağılımını ve bireşimini düzenlemiş; cümlelerin birbirine bağlanmasını, birbirinden ayrılmasını birbiriyle birleştirilmesini fesahat ve belagat ilimleri çerçevesinde anlatmışlardır. Bağlayıcılar ekseninde ve "anlamın temel kalıbı cümle" bağlamında tarassut edilerek (gözlenerek) yapılan fikri ameliyeler ile cümlenin mahiyeti, mahiyetin hem zihinde hem dış dünyadaki özü, nitelik ve özellikleri ortaya konulmaya çalışılmıştır.

Cümle ve cümleden büyük dil birliklerinin varlığı ve içlemi ile bunların birbirlerine bağlanmaları, birbirleriyle birleşmeleri ve birbirlerinden ayrılmaları Türk cümlesinin uzun soluklu serüveni içinde farklı yönleri ve boyutları ile ele alınmış, bağlayıcıların ve bağlayıcılarla ortaya çıkan "anlam halkaları”nın görünüşüne evrilerek işlenmiştir. Bir yönüyle bağlayıcı kelimelerin diğer yönüyle bağlayıcı işaretlerin varlığ i ile ilgili olan bu husus, Türkçenin belagat semantiğinde sözlük birimleri ya da bunların oluşturduğu düğümleri birbirine bağlayan cümle ve cümleden büyük dil birliklerinin yeterlilikleri ve sinırlılıkları çerçevesinde tekâsüf ve tekâmül ettirilmiştir. Bu meyanda anlam taşıması ve tam bir yargı bildirmesi bakımından cümle ile kelam arasında bağlayıcıların işlevi ekseninde ilişkiler kurulmuş; cümle ve kelam içerik ve içerimleri (kaplam ve içlemleri) umumilik ve hususilikleri yönleriyle karşılaştırılarak münakaşa ve münazara edilmiştir. Kelamda isnat (yargı) ve anlam (ifade) bulunduğu, cümlede anlam bulunmadığı sadece isnat olduğu görüşü ile işlev ve anlam birlikteliğine veya ayrıklığına dayalı değerlendirmeler yapılmıştır (Şimşek, 2018: 276, 277).

$\mathrm{Bu}$ tartışma ve münakaşalar içinde cümleyi manasını bir nesneye irca (indirgeme) ile beyan etmek; kelamı ise evveline sarf ve irca eyleyerek (daha kolay ve yalın duruma getirerek) ifade etmek yaygın bir kabul haline gelmiştir. Nitekim Tanzimat dönemi eğitimcisi ve dilcisi Selim Sabit, Miyâru'l-Kelam'da Fasl-ı Evvel Der-Beyân-ı Telîfi Kelam başlı̆̆ altında kelam’ı: “murad ve maksudu beyan ve dolaylı 
ifadesinde irad olunan nutuk ve ibareyi birtakım cümle ve yardımcı cümleden terekküb eden birim”, cümle'yi: "dahi bi'l-hükm iki lafzdan teşekkül ederek muhataba faidei tamme (tam bir fayda) sağlayan söz” diye tarif etmiş (Gökçe, 2006: 65) kaplam ve içlem olarak cümleden daha geniş ve daha büyük dil birimi olarak tanıtmıştır. Tanzimat dönemi dilci ve lügatçilerinden Ali Nazıma ise kelam ile cümle arasında kaplam ve içlemden hareketle yaptığı mukayesede kelamı: "tam bir fikrin ifadesi ve cümleden büyük fenni meani” olarak ifade etmiş (1329: 189-190) ve dikkatleri cümleden büyük dil varlıklarına diğer bir ifadeyle "anlam halkaları"na çevirmiştir. Günümüz dil bilim yaklaşımlarında benzer şekilde bazı cümlelerin bir duygu ve düşünceyi tek başına anlattığı bazı cümlelerin ise tek başına anlatamadığı bu sebeple“anlam halkası" oluşturacak ve bütün düşünceyi anlatacak cümleden büyük ve kapsayıcı dil birliklerinin var olması gerektiği tartışılmış, konu ile ilgili çeşitli görüşler ileri sürülmüş, adlandırmalar yapılmış ve mahiyetin özü ortaya konulmaya çalışılmıştır.

Cümlelerin tam bir fikri ifade etmeye yetmediği anlayışıyla cümle sınırlarını aşan ve bir ya da birçok cümleden oluşan daha üst düzeydeki dil birliklerine yönelik çalışmalarla cümleden büyük söz zinciri parçaları (sözceler) incelenmeye ve bunların birbirlerine eklenme kuralları araştırılmaya başlanmıştır. Dil bilimci Zellig S. Harris'in cümleleri önceleri dağılımsal açıdan, sonraları söylem çözümlemesi açısından incelemesiyle cümlelerin birbirinden ayrılma, bağlanma ve birleştirilmeleri irdelenmiş; incelemelerde kimi araştırmacılar anlamı, kimileri işlevi esas alıp cümleleri kullanıldıkları yere ve zamana, kendinden önce ve sonra gelen unsurlara, kazandıkları farklı anlam ve değerlere göre çözümlemişlerdir (Vardar, 2002: 179, 180). Çözümlemeler, ister ayrı ayrı ister bağlanarak oluşturulsun aynı "anlam halkası" içinde yer alan ve anlamca birbirini tamamlayan cümlelerin farklı formlarda oluşturulabileceğini ortaya koymuştur.

Günümüzde ise bilişsel bilimci ve felsefeci Jerry Alan Fodor ve dil bilimci Jerrold Jeccob Katz tarafından sistematize edilen yorumlayıcı anlam bilim, Doğu belagatindeki sebkimevsul, sebkimefsul ve sebkimürekkep konularının işletimine benzer bir konfigürasyonu esas almış ve gösterenle gösterilen arasındaki ilişkileri gözeterek sözcelerin anlamsal ve dil bilgisel ulamlarla anlam ayırıcı ögelerini bu ögelerin bağdaştırılmasını, bağlaşıklarının oluşturulmasını ortaya koymuştur. Buna göre cümlelerin birbirine göre konumunu tayin eden cümlelerin anlam bütünlügüdür. Cümleler murad ve maksadı beyan ve dolaylı olarak ifade etmede "anlam halkaları" veya "anlam kümeleri oluşturarak birleşir; bağlı veya birleşmez; kesik ve ayrı yazılır. Bunu belirleyen irad olunan söz ve ibarenin birtakım cümle ve cümle ile ilgili ögelerden terekküp ile ifadenin tam bir fikrin ifadesi olarak ortaya çıkması ve yazarın üslupla ilgili meani-sözü duruma ve yere göre uyarlama tercihidir (Nazıma, 1329: 189-190).

Klasik Arap ve Osmanlı nahvinde ibarenin tarz ve terkibini belirlemek (sebk) ve ibareleri birbirine benzetmek, müsavi ve müşabih kılmak (temasük) olarak adlandırılan bu durum, modern dil biliminde bağdaşıklık (ittisak) adını alır. İttisak, dil birliğini oluşturan parçaları ve segmentleri bir araya getirerek parçalar arasında bağlantıyı (sebk) sağlamak ve dil ve lügat araçlarını doğru ve yerinde kullanmakla olur (Daşkıran, 2018: 402). Bu bağlamda bağlayıcılar, cümleleri metinsel yapıya götüren ve ittisakı sağlayan unsurlar olarak kullanılır. Bağlayıcılar, bağlaşık ve bağdaşık dilsel birim ve iletişimsel olgu olan ve cümleler arasında çeşitli düzeylerdeki ilişkilerle oluşturulan metinleri belli koşullar altında ve belli uygulanma düzleminde gerçekleştirir; anlamını çeşitli açlardan belirginleştirir ve bütünlerler. Buna göre metin oluşturulması için lafızlar arasında irtibat olmalı, lafızlar dizi halinde bağlanmalı, kavramlar arasında bağdaşma, kaynaşma, uyuşma, uygunluk (imtizaç) ve tutarlılık (insicam) bulunmalı; metin ve lafız mefhumları birbirini destekleyecek ve o mevzuyla alakalı başka metinleri hatırlatacak bir çağrışım (tedai) mahiyetinde kullanılmalıdır (Araz, 2016: 45). 
Dili cümleyle sınırlandıran üretimsel dönüşümlü dil bilimine tepki olarak metin dil bilim, cümleler arasındaki anlam ilişkilerini esas alır (Aksan, 1995: 257) ve "anlam halkaları"nın varlığına işaret ederek metni oluşturan cümleden büyük dil birliklerinin varlığını kabul eder. Terminolojik adlandırılmalarında farklılıklar, fakat bakış açılarında benzerlikler bulunan bu kapsayıcı dil birlikleri için Üstünova, "cümleden büyük birlik" (1998: 2); Akçataş, "bağımlı cümle grubu" (2007: 7); Vardar, "sözce" (1988: 189); terimlerini kullanmış cümle ve metin bağlamındaki konuları, belagat ilmindeki meaniye karşlık gelen bir konfigürasyonda değerlendirmişlerdir. Düşüncenin anlatımında cümlenin yetersiz kaldığı ve eksiz önermeye ancak cümleden büyük birlikler (CBB)'le ulaşılacağı yaklaşımının sonucunda aynı konuda söylenmiş cümlelerle birlik oluşturan üst yapılarda anlamsal bağın esas olduğu ve dil bilgisel bağın buna ancak hizmet ettiği ortaya konmuş (Üstünova, 2001: 786); dil bilgisi göstergelerine dayanılarak "anlam halkaları"nın yeterlilikleri ve sınırlılıkları belirlenmeye çalışılmıştır.

Türkçe cümle düzeneği, difüzyonik (yayılma ve yayınma) özelliği ve diyakronik (art zamanlı gelişim ve değişim) kurallarına bağlı olarak, aralarında anlam ilgisi bulunan cümlelerle aynı veya farklı yönde geliştirilerek ve cümle bağlama-ayırma-birleştirme yöntemleri ile ilişkilendirilerek dizilenebilir. Kavram derinliği ve anlam zenginliği içeren bu dizilenmeler, Türk cümlesinin belagat semantiğinde çeşitli "anlam halkaları" oluşturur ve Türk cümlesine geniş bir söyleyiş ve ifade imkanı kazandırır. Metni merkeze alan bu dizilenmelerde cümlelerin birbirleriyle iltisaklı olması, cümleler arasında içsel tutarlılık, kapsam geçerliği ve anlam bütünlüğü bulunması şarttır.

Cümleden büyük dil birliklerinin "anlam halkaları" oluşturacak biçimde kullanımı, sağlam ve doğru anlatımda cümle birleştirmeye ve bağlamaya imkan tanıyan ve düşünceleri tek bir yargıda toplayan geçiş ve bağlantı ifadeleri ile yani bağlayıcılarla yapılır. Türkçede cümle bağlama, ayırma ve birleştirme işlemi, dilin sözcelem yazma sürecinde ürettiği somut ileti sözcede ve sözceleri belli bir bağlam ve durum içinde gerçekleştirme edimi olan sözcelemede (Kıran, 1999: 94 \& Kerimoğlu, 2017: 139) en ileri seviyede gerçekleşir. Bu sayede ortaya birbirine denk ve eşlenik söyleyişler, aksiyomatiko-deduktif (doğruluğu kabul ve ispat edilen kavramlara dayalı) söz ve ibareler çıkar. Örneklemeler ve uygulamalar etki ya da önemine istinaden cümleden büyük dil birliği (söz dizimsel bileşen) olarak kullanılan ve "anlam halkası" oluşturan bu tür cümlelerin birbirlerini tamamlar biçimde birleştiğini, birbirlerini açılar veya yorumlar biçimde bütünleştiğini ve konvansiyonel (anlaşmalı-uzlaşmalı) ilişkiler içinde kullanıldığını ortaya koymuştur.

\section{Doğru ve sağlam anlatımda cümle bağlama ayırma ve birleştirme}

Arap nahvi(söz dizimi-cümle bilgisi) ve onun etkisindeki Osmanlı nahvinde kelimelerin cümle içinde söz dizimi kurallarına göre sıralanmasına inşa, cümle ve cümleden büyük dil birliklerinin, makamın ve halin icaplarına göre uygun biçimde ve yalından karmaşı̆̆a, bütünden parçaya, zorunludan olasıya, öncülden soncula giden bir düzenleme içinde bireşimine (terkib edilmesine) sebk adı verilir. Sebk, bağlı olmayan ayrı ve bağımsız cümlelerle anlatım (sebkimefsul), bağlı ve zincirlemeli müselsel cümlelerle anlatım (sebkimevsul) ve hem bağlı hem bağsız karışık cümlelerle anlatım (sebkimerekkeb) olarak ortaya çıar (Güneş, 1999: 50,51). Dil bilimi ve dil felsefesinde, dilin inşa (dilek) ve haber (hüküm) gibi iki temel cümle kategorisinden birisi olan inşa, belagat ve fesahat ölçülerine göre söylenmiş veya yazılmış cümlelerin söz dizimi kurallarına göre vasıl ve fasıl yöntemleriyle artırılması, çoğaltılması ve genişletilmesi ameliyesidir. Bu ameliyede vasıl, bir cümleyi başka bir cümleye isnat etmek ve nispet ederek bağlamak, başka bir cümle ile arada bağlayıcı olduğu halde kullanmak; fasıl bağlamayı terk ederek cümleyi başka bir cümle ile fakat arada bağlayıcı olmadan kullanmaktır. Bu şekilde sebklerden birisine nedensellik ilkesi ile bağlanılan cümleler, ayırma-uzak bırakma (tefrik edilme) ve kavuşturma- 
ulaştırma (tavsil olunma) yoluyla dile getirilir (Durmuş, 2000: 335). Bu ameliyede cümlelerin ve cümleden büyük dil birliklerinin aynı anlam ve kavram alanında bulunması ve kelimelerin ortak "anlam birimcik"lerine sahip olması şarttır.

Cümle bağlama, ayırma ve birleştirme, anlam açısından ortak bir paydaya sahip kendi içinde benzerlikler gösteren sözlüksel birimlerin, içerik düzlemindeki bağıntılarıyla gerçekleşir. Temelinde dilin sözlük ve anlam boyutlarını yapılaştırma ve anlamı belirleyen sözlüksel yapıları söz dizgesi aracılı̆̆ıyla bütün biçimde betimleme çabası yer alır. Cümlelerin bağlayıcılarla doğru bağlanması aynı sözlüksel alanda yer almış ve aynı tem etrafında kümelenmiş kelimelerin bir araya ve tek anlamlı duruma (monosemiert) getirilerek ve cümle kuruluşunda kapsayıcı yön ve birleştirme yönü (=ciheti camia)ne riayet edilerek ayn "anlam halkası"nda cümleler oluşturulmasıyla mümkün olur. Buna göre ardışık olarak sıralanmış bu oluşumlarda cümlelerin özneleriyle yüklemleri arasında münasebet ve mukayese yönü bulunması ve cümlelerin yahut cümleden büyük dil birliklerinin anlam bütünlüğünü oluşturan "anlam bilimsel yerdeşlik"in sağlanmış olması gerekir. Ortak bir paydaya indirgenmiş içerik düzlemindeki bu kabil ilişkilerle, cümlelerin bir düzen ve kural dahilinde birbirinden ayrılması, birbirine bağlanması ya da birleştirilmesi böylece söyleyişte makbul, bilgide matlup (istenilen, arzulanan) cümleler oluşturulması sağlanır (Özdoğan, 2012: 63-65). Türkçe belagat semantiğinde cümle ve cümleden büyük dil birliklerinin oluşturabileceği cümle formları aşağıdaki konfigürasyonlarda gerçekleşir:

\section{2.a Kesik ve ayrık cümlelerle anlatım - (Ayırma: Sebkimefsul)}

Kesik ve ayrık cümlelerle anlatım (sebkimefsul) bağlayıcılarla bağlamayı terk etmek; ardışık cümlelerde kimi durumlarda "ve" bağlacını kullanmayarak birleşmeyi ortadan kaldırmaktır. Sebkimefsul cümleler arasında ayırma ve ayrıştırma (fasıl) tam bir irtibatllık (ittisal ilal gaye) veyahut tam bir irtibatsızlık (infisal ilal gaye) halinde söz konusu olur (Demirci, 2017: 43). Sonraki cümle ile önceki cümle arasında bağlantılılık varsa ve birliktelik söz konusu ise sonra gelen cümle önceki cümleyi tafsil ve îzah ederek belirtmiş ve tamamlamış; bağlantısızlık ve ayrıklık varsa isnadı yüklemenin merkezine alarak manasına vurgu yapmış ve kuvvetlendirmiş (berkitmiş) olur.

Kesik ve ayrık cümlelerle anlatımda cümlelerden her ikisinin de isim cümlesi veya fiil cümlesi olması gerekir. Bununla birlikte her iki cümlenin isim veya fiil cümlesi olması durumunda aralarında ortak bir yön yoksa birleştirme yine gerçekleşmez. Böylece ardışık iki cümle arasında tam bir kopukluk (kemali inkıtâ) olduğu ve bu cümlelerin aralarında "ve” bağlacı kullanılmadığı için dinleyenin yanlış anlamasına yol açmamak kaydıyla fasıl yapılır. İki cümle arasında kısmi ilgi bulunması (şibhi kemali ittisâl) veya ikinci cümle ile birinci cümlenin anlamının bütünlük göstermesi ya da ikinci cümle ile birinci cümle arasında bütünlük yerine güçlü bir bağın bulunması durumunda ise kesik ve ayrık cümlelerle anlatım (sebkimefsul) yerine vasıl yapılır (Durmuş, 2012: 206 \& Sevinç 2017: 56-58).

Kesik ve ayrık cümlelerle anlatım (sebkimefsul) nedenselliği ve olay örgüsündeki bağlantı sağlamlığını bozan süreksiz ve kopuk fragmantel anlatım değildir. Kesik ve ayrık cümlelerle anlatım aralarında bağlayıcı bulunmayan, fakat uygunluk, yakınlık ve ilgi gibi mensubiyet ilişkisi ve birleştirme yönü bulunan aynı konu etrafında ve aynı "anlam halkası" içinde söylenmiş cümlelerin yer aldığı ve ayrıntılarıyla tanıtlandığı bütünsel ve figüratif bir anlatımdır. Buna göre:

"Taşbaş sabırsızlıktan çatlıyordu. Kararını vermişti ve geceyi bekliyordu. (Yer Bakır Gök Bakır, Yaşar Kemal)” 
“(Taşbaş) kararını vermişti." cümlesi öndeki “(Taşbaş) geceyi bekliyordu.” cümlesi ile aynı bağh cümlenin içinde bulunmakla birlikte benzer özellikler (anklav) göstermemekte, iki farklı cümleyi birbirinden ayıran dereceli bir ilişki göstermektedir. Bu cümlede, soru ve cevap cümleleri arasında olduğu gibi "(Taşbaş) kararını vermiş̧i." cümlesinin takip eden gizli veya açlk soruya cevap konumundaki "(Taşbaş) geceyi bekliyordu." cümlesi ile anlamsal ortak yönü olmadı̆̆ından fasıl yapılmıştır. Buna göre birinci cümle ile ikinci cümlenin içeriklerinin farklı olması ve iki cümle arasında kapsayıcı yön ve birleştirme yönü (ciheti camia: ortak yön) bulunmaması durumunda cümleler arasında fasıl yapılması "ve" bağlacı kullanılmadan fasıl ile ayırma yani istinaf (yeniden başlama) yapılması gerekir. Böyle bir kullanımda ilk cümle ile önündeki cümle "ve” bağlayıcısı ile bağlanmaz.

"Tren bir masal boşluğu içinde uçup gidiyor ve artık dışarıda herşey birbirine benziyor." (Hayat Böyledir İşte, Tarık Buğra)"

Cümlesinde "ve" bağlacı ile yapı ve anlam bakımından herhangi bir ortaklığı bulunmayan, özneleri ve yüklemleri farklı iki cümle, birisi hareket diğeri durum bildiren iki ayrık fikir ve iki ayrı "anlam birimcik (sem)" aynı hükme ortak edilerek (iştirak) aynı "anlam halkası" içinde bağlanmaya çalışılmıştır. Halbuki "ve" bağlacı bu kullanımda birliktelik ve beraberlik bildirmekten ve bağlama yapmaktan uzaktır. Birbirinden ayrık olan ve ortak münasebeti bulunmayan bu cümlelerin eşit şartlarda bir araya getirilmesi ve aynı hükme ortak edilerek (iştirak) kullanılması söz konusu değildir. Cümlelerin kapsayıcı yön ve birleştirme yönü (=ciheti camia) gözetilerek aynı hükme bağlanması ve bağlama edatı "ve" den önce kendisine bağlanılan veya "ve" den sonra kendisine bağlanan biçiminde dizilenmesi böylece:

"Tren bir masal boşluğu içinde uçup gidiyor... Artık dışarıda herşey birbirine benziyor.” biçiminde düzenlenmesi gerekir.

Kesik ve ayrı cümlelerle anlatımda birbirini izleyen cümleler, mantıkî-lojik düzenlemeye uygun dizilirler. Bu dizilenmede birden fazla cümle "anlam halkası" oluşturacak ve bütünlük taşıyacak biçimde bir arada kullanılabilir.

\begin{abstract}
"Bir zabit arkadaşımla oturuyorduk. Yanımızdaki masada kocaman kalpaklı bir babayiğit, çetin bir Çerkes şivesiyle yanındaki kalpaklılara birşeyler anlatıyordu. Daha Kafkasya'dan yeni gelmiş sanılacaktı. "Demek yollar açıldı!" dedim. Arkadaşım, "hangi yollar diye yüzüme baktı". "Hangi yollar olacak. Karadeniz yolu!” “Nereden bildin? “Baksana şu Çerkes'e...” İşte yeni gelmiş olacak. Sağımızda yanağından kan damlayan iri Çerkesi gösterdim. Arkadaşım bir kahkaha attı. Ne gülüyorsun dedim. “Ayol o Çerkes değildir.”Dedi. Ey lisanına ne diyeceksin? Çerkes taklidi yapar. Güldürmek için mi? Hayır... Ya niçin? Kendini Çerkes zannettirmek için... (Bir Kayışın Tesiri, Ömer Seyfettin)
\end{abstract}

"Anlam halkası" oluşturan bu cümlelerde olay ve olgular, karakter ve tipler mantıksal ve nedensel ilişkiler gözetilerek anlatılır. Doğru ve sağlam cümlelerin ve cümleden büyük dil birliklerinin oluşturduğu "anlam halkaları"nda tek bir cümlenin doğruluk değeri, birden çok cümlenin doğruluk değerinde tek tek tutarlı ve geçerli bir ilişki sağlar. Bu kullanımlarda cümle hem tek başına hem ayrı ayrı tek bir doğrusal değere sahiptir. Bu itibarla cümlelerin fraktal (parça cümle) boyutu ve kendine benzerlik boyutu değerleri aynıdır.

\title{
2.b Bağlı ve zincirlemeli (müselsel) cümlelerle anlatım-(Bağlama: Sebkimevsul)
}

Bağlı ve zincirlemeli cümlelerle (sebkimevsullü) anlatım, temel metnin içerdiği ve kapladığı cümleleri, öznede ve yüklemde birleştirerek ve isnat ederek birbirlerine bağlamaktır. Bağlama (sebkimevsul) ögelerin aynı hükme ortak edilmesi (iştirak) ve bağlayıcılarla bağlanması suretiyle gerçekleştirilir. Bu bağlamada esas bağlayıcı "ve” olmak ve üzere “,” ve “;” gibi bağlayıcılar da bağlama vazifeli olarak 
kullanılabilir. Bağlanan ögeler çeşitli bağıntılar ve bağlantılar gerçekleştirir, "ve" den önceki veya "ve" den sonraki ögeler olarak eşit şartlarda ve eşlenik biçimde dizilenirler. Dizilenmede sebep-sonuç veya ardışıklık ya da ikisi birden gerçekleşir (Kızılkaya, 201: 1373).

Bağlama (sebkimevsul) yapmada temel amaç, cümle veya cümleden büyük dil birliğinde tekrarlanan ve yerdeşlik yaratan “anlam birimcik (sem)"ler yardımıyla özne, yüklem ve tümleçleri kendi görünüşlerinde kullanmak; aynı kavram etrafında öbekleşen benzer ya da türdeş cümleleri ise birbirine sebk ve vasıl etmektir. Bu oluşumda cümlelerin özneleriyle yüklemleri arasında mukayese yönlerinin (karşıtlık-zıtlık, benzerlik-aynılık) ve cümlelerin yahut cümleden büyük dil birliklerinin anlam bütünlüğünü sağlayan "anlam bilimsel yerdeşlik"in bulunması gerekir. Cümlelerin birbirine bağlanabilirliği gözetilerek birleştirme yönü (=ciheti camia) üzerinde, ortak “anlam birimcik (sem)”ler aracıllğıyla anlamsal kesişim kümesi ve arakesiti oluşturularak sağlanır (Özdoğan 2012: 52-57).

Aralarında işlev ve görev bakımından ortaklık bulunan bu cümleler, tek başına tam bir anlam taşıyorsa, hükmün bütün niteliklerinde değil, sadece asıl hükümde (yüklemde) ortaklık gösterir. Aynı şekilde eksik bir cümle, tam bir cümle üzerine atfediliyorsa bağlandığı veya dayandırıldığı tamcümlenin bütün kayitlarında cümle ile ortak olur (Hacıbekiroğlu, 2015: 82, 87). "Ve" ile yapılan bağlamanın doğru ve sağlam bir bağlama oluşturması için kendisine bağlanılan’ın (matufun aleyh’in) kelime ya da cümleleri, edatlar yoluyla, bağlanan (matuf) ile birleştirmesi ve kendisine bağlanılan ya da bağlanan'lardan birinin düşünülmesi ile diğerini de hatıra getiren münasebetler oluşturması (tezâyüf) böylece cümlelerdeki fikri ortak hükme bağlaması gerekir. Aynı şekilde karşılaştırılan bu cümleler arasında kıyas yapılacak derecede benzerlik (müşabih), eşlik (temâsül), yoruma dayanan yarı benzerlik (temasül), yarı zıtlık (tezat şibhi temâsül), zihinde birleştirme yapacak bir alaka ve münasebet ile kapsayıcı yön ve birleştirme yönü (=ciheti camia) bulunmalıdır (Filizok, R. \& Akdeniz, S. http://www.egeedebiyat.org/docs/608.pdf. 4/37, erişim tarihi 2019 ).

Oysa atıf ve rabıt işlevi hakim ve baskın olan "ve" bağlayıcısının, kapsayıcı yönü ve birleştirme yönü (=ciheti camia) gözetilmeden sadece anlam veya sadece işlev boyutu gözetilerek oluşturulan ve doğru olmayan cümlelerin kullanımları yaygındır. Bu kabil kullanımlarla münasebetle ilgide makbul, malumatla ilgide matlup sağlam ve doğru anlatımlı cümleler gerçekleştirilemez.

“Defterdar Mehmet Paşa ile Erzurum'a gelen ve orada gümrük kâtipliği yapan Evliya Çelebi, şehrin kapılarından bahsederken, bunların dört kapı olduğunu ve yabancı tüccarların Gürcü Kapısı'nda oturduklarını söyler. (Beş Şehir, Ahmet Hamdi Tanpınar)"

bağlayıcıların hem işlev ve hem anlam yönü gözetilerek yapılması gereken böyle bir bağlamada bağlamanın şekli yönü ile ilgilenilerek anlam; anlam yönü ile ilgilenilerek şekil yönü ihmal edilmiş ve aykırı bağlamalar yapılmıştır. Cümle "ve" bağlayıcısı ile bağlanmasına ve bağlı ve zincirlemeli müselsel cümlelerle anlatım (sebkimevsul) oluşturmuş gibi görünmesine rağmen ögelerin yerinde ve doğru kullanılmaması ve takdim-tehir oluşturacak biçimde sıralanması yüzünden bağlı ve zincirlemeli müselsel cümlelerle anlatım (sebkimevsul) gerçekleştirilememiş; cümle kastettiği anlamı ortaya koyamamıştır. Cümlede, bağlamanın şekil boyutu zahiren tamamlanmış, fakat anlam boyutu tamamlanamamış ve eksik kalmıştır. Bağlayıcıların doğru ve yerinde kullanılması ile kastedilen anlamın ortaya konulabilmesi için cümlenin ve bağlayıcısının kullanıldığı yapılar esas alınarak:

I- birinci “ve” bağlayıcısının bulunduğu bağlama grubunda:

"Erzurum'a Defterdar Mehmet Paşa ile gelen ve orada (Erzurumda) gümrük kâtipliği yapan Evliya Çelebi", 
biçiminde takdim-tehir yapılarak anlamdaki karışıklığın giderilmesi ve Defterdar Mehmet Paşa ile Erzurum'a birlikte gelinmekle beraber orada gümrük katipliğinin birlikte yapılmadığı anlamının verilmesi gerekir. Bu sebeple "ve” bağlayıcılı bağlama grubu,

a) vasıl yapılacaksa,

“Erzurum’a Defterdar Mehmet Paşa ile gelen ve orada (Erzurum’da) gümrük kâtipliği yapan Evliya Çelebi”

biçiminde veya,

b) fasıl yapılacaksa:

“Evliya Çelebi, Defterdar Mehmet Paşa ile Erzurum’a gelir . Orada gümrük katipliği yapar.”

biçiminde yazılması gerekir.

II- ikinci "ve” bağlayıcısının bulunduğu bağlama grubunda ise:

“(Evliya Çelebi) şehrin kapılarından bahsederken, bunların dört kapı olduğunu ve yabancı tüccarların Gürcü Kapısı'nda oturduklarını söyler. (Beş Şehir Ahmet Hamdi Tanpınar)”

"Şehrin kapılarından bahseden Evliya Çelebi bunların dört kapı olduğunu söyler” ve "Evliya Çelebi yabancı tüccarların Gürcü Kapısı'nda oturduklarını söyler.”

cümlelerinin her ikisi de fiil cümlesidir ve her iki cümlenin öznesi de yüklemi de aynıdır. Cümleler şeklen birbiri ile uyumludur, ancak manen birbirleri ile uyumlu değildir. İkinci cümledeki "yabancı tüccarların Gürcü Kapısı’nda oturdukları" sahipliği, birinci cümlede kast edilen "bunların dört kapı olduğu” biçimindeki dört sahipliğin veya bulunmanın kendisi ya da "anklav"ı değildir. Dolayısıyla yan cümle ana cümlenin içinde bulunmakla birlikte, ana cümle ile benzer özellikli ilişki "anklav" göstermemekte; ana cümle ile tedrici dokanak ilişkisi göstermektedir.

Cümle: “bu kapılarn Tebrizkapı, Gürcükapı, Erzincankapı ve Yenikapı olduklarını söyler.”

biçiminde kurulsaydı ikinci cümle birinci cümlede kastedilen dört sahipliği veya bulunmayı ifade edecek böylece cümleler belagatteki "Özel Lafzı Genele Atıf” kuralına göre birbirleri ile manen de uyumlu olacaklardı.

Türkçe cümle konfigürasyonunda bağlama işlevi gören bağlama edatı "ve” yanında bağlama işaretleri “, “ve “;”, bağ-fiil (y)Xp, sebkimevsulü sağlayan ve gerçekleştiren bağlayıcı ögeler olarak yaygın biçimde kullanılabilir. Bağlayıcıların yerinde ve doğru kullanılmasıyla söz, ibare ve cümleler arasında anlamlı birliktelikler oluşur, cümlelere sağlamlık ve edebilik kazandıran ahenkli ve armonili dizimlikler ortaya çıar.

I-“Gözlerini pencereden ve kulaklarını kapıdan ayırmıyordu. (Mahşer, Peyami Safa)”

II-“Sesine metanet ve başının hareketlerine hakimiyet gelmişti. (Mahşer, Peyami Safa)"

cümlelerinde hem yapı hem anlam yönünden tam bir mutabakat (kemali ittisal) vardır. I. cümlede "ayır" ortak yükleminden yararlanılarak cümle ögeleri arasında yapı yönünden, göz-görme-pencere ve kulakduyma-kapı kelimelerinden yararlanılarak mana yönünden II. cümlede "hakimiyet gel-" ortak yükleminden yararlanılarak yapı, ses-metanet ve baş (hareket)-hakimiyet kelimelerinden yararlanılarak 
mana yönünden ilgi kurulmuş (tenasüp) duyular arası birleştirme yapılmıştır. Cümleler lafzen ve manen uyumlu oldukları ve aralarında uyumlu olduklarını gösteren ortak yön, kapsayıcı yön ve birleştirme yönü (=ciheti camia) bulunduğu için "ve" bağlayıcısı ile bağlanmışlardır. Bu itibarla cümlelerin birbirine atfedilmesi ve bağlanması doğrudur.

I. "Her şeye, bütün güzelliklere ve ileriliklere layık olduğu halde bu durumda bulunan Türkiye ve bütün Türkiyeliler, din kardeşleri, kan kardeşleri kurtulacak,(;) yamru yumru mekteplerin, pis hastanelerin, izbe gibi evlerin yerini pırıl pırlları alacaktı. (Firavun Imanı, Tarık Buğra)"

cümlesi ise,

kelimeleri, kelime gruplarını veya cümleleri biçim veya anlam yönüyle birbirine bağlayan “,” bağlayıcısı ile bağlanmış ve birbiri ardınca sıralanan bağlı ve zincirlemeli cümlelerle (müselsel) anlatım (sebkimevsul) gerçekleştirmiş gibi görünse de cümlede eşlenik bağlama yapılmadığı ve ", bağlama işareti doğru kullanılmadığı için sebkimevsul gerçekleştirilememiş ve cümle kendisini oluşturan unsurların kasdettiği anlamı ortaya koyamamıştır. Buna bağlı olarak cümlenin anlam boyutu tamamlanamamış şekli boyutu ise eksik kalmış ve zahiren tamamlanmıştır.

"Ve” bağlayıcısına muadil bir işlevde kullanılan “,” birbirine eş ve denk yapıları bağlar. Buna göre art arda cümlelerle sıralanmış bu oluşumda “(;)"den önceki ve sonraki cümlelerin kendi içlerinde özneleriyle yüklemleri arasında bağlanmayı mümkün kılacak münasebet ve mukayese yönünün bulunması ve metnin anlam bütünlüğünü sağlayan "anlam bilimsel yerdeşlik”in sağlanması gerekir. Yukarıdaki cümle için:

I-bu durumda bulunan Türkiye kurtulacak, (bu durumda bulunan) bütün Türkiyeliler kurtulacak, (bu durumda bulunan) din kardeşleri kurtulacak, (bu durumda bulunan) kan kardeşleri kurtulacak " ve

II- pis hastanelerin (yerini), yamru yumru mekteplerin (yerini), izbe gibi evlerin yerini "

denir, çünkü bunlar arasında tamlananda birleşen ve ortak payda oluşturan bir ilişki vardır. Bu ilişkide anlam birimin gösterilen bölümü "sem"ler, bağlanan ile kendisine bağlanan arasında hem lojik ve hem sentaktik bir münasebet kurmuş ve işlev ve anlam yönünden "anlam halkaları” oluşturmuştur.

Oysa “,” ile bağlanan oluşumda: "bu durumda bulunan Türkiye alacak.” veya "bu durumda bulunan bütün Türkiyeliler alacak." denemez, zira "bu durumda bulunan Türkiye kurtulacak." ile "izbe gibi evlerin yerini purl pirlları alacak."

"Türkiye" ve "ev" "anlam birimcik (sem)”lerinin arasında akıl yürütme ve muhakeme (uslamlama) ile kavranan bir bağıntı, bağlanmayı mümkün kılacak sentaktik bir münasebet yoktur. Bu itibarla metnin anlam bütünlüğünü sağlayan "anlam bilimsel yerdeşlik"in gerçekleştirilmesi ve cümlelerin birbirine bağlanması olanaklı değildir. Metni oluşturan cümleler “...kurtulacak” yükleminden sonra (,) ile değil (;) ile bağlandığı takdirde

"Türkiye...kurtulacak ve din kardeşleri...kurtulacak" (;) yamru yumru mekteplerin, pis hastanelerin, izbe gibi evlerin yerini pırıl pırıl (mektepler, hastahaneler, evler)ları alacaktı."

cümleleri arasında özne, nesne ve yüklem gibi ögelerle belirli bir sentaktik münasebet kurulacak, semantik alaka sağlanacak böylece kendisi içinde ortak bileşeni olan bu cümleler, birbirlerine bağlanabilecek ve lafzın delaletini ve sözden kastedileni sağlamak üzere birlikte kullanılabilecektir. 
Sebkimevsulle söylenen veya yazılan cümlelerde doğru bağdaştırma yapması ve bağlaşıklık kurması koşuluyla "de" bağlayıcısı da bağlama işlevi ile kullanılabilir. Bununla birlikte,

"Taş atıp da kolun mu yoruldu. (deyim)”

cümlesinde "de" bağlayıcısı böyle bir işlev gerçekleştirememiştir. Cümle:

I-“taşı attın diye kolun mu yoruldu!" veya

II-“taş atıp da kolun(u) mu yordun!” olmalı, çünkü:

bağlayıcılarla yapılan ve bağlama grubu olarak ortaya çıan dil birliklerinin en temel özelliği birbirine uygun, birbirleriyle uyumlu yapılar oluşturması, bağlanan ögeler arasında gruplandırma ve öbeklendirme bakımından tam bir eşleniklik ve denklik taşımasıdır.

Dizimsel ve dizisel ilişkiler bağlamında satır-sütun paradigmasında karşılaştırılan ögelerin bulunduğu veya bulunması gereken sütunlardan herhangi birisinde bir eksiklik veya uyumsuzluk varsa ortaya çıan kelime grubu yanlış oluşmuş veya yanlış bağlanmıştır."

I-“Hâlâ gözler sımsıkı kapalı, ses sakin(;) fakat yalnız şişik ve kısık yüzünde değil, bütün zavallı vücudunda korkunç bir intizar var. (Sinekli Bakkal, Halide Edip Adıvar)”

II- Fazla acıkmış insanlar gibi, ne verirlerse, bakmadan yutuyor ve memnun oluyordu. (Kızılcık Dalları, Reşat Nuri Güntekin)

cümleleri doğru bağlanmamıştır. I. cümlede yüzün içinde bulunduğu "kısık hal” kendisinin özelliği değildir. Şişik (vücut ve göz için: kabarık, şiş) ve kısık (ses için: kısılmış güçlükle çıkan, boğuk) kelimelerinin anlamı diğerine eklenebilir olmadığı için aralarında atıf (bağlama) yapılamaz. II. cümlede ise cümlelerin özneleri ortak olmakla birlikte cümlelerdeki "memnun olmak" ve "yutmak" "anlam birimcik (sem)"lerinin kapsayıcı yön ve birleştirme yönleri farklıdır ve aralarında ortak yön (ciheti camia)bulunmadığı için vasıl yapılarak bağlanmaları doğru düşmemiştir.

Bağlama öbeğinde denetimi olan ve düğümü oluşturan merkezi birleşen konumundaki bağlayıcı işlev ve anlamı değiştirmek suretiyle dilsel ögelerin gerçekleştirilmesinde ve olgunun diğerine dönüşmesinde köprü görevi görür.

I-“Ev sahibi, onu akşama kadar güçlükle zapt etti ve Yusuf Edremit'e ertesi gün gitmeye razı oldu. (Kuyucaklı Yusuf, Sabahattin Ali)"

II-“Ne de olsa Edremit'in yerlisiydi ve ailesinin itibarını düşünürdü. (Kuyucaklı Yusuf, Sabahattin Ali)"

cümleleri "ve" bağlama edatı ile bağlanmasına ve sebkimevsul gerçekleştirilmiş (gibi) görünmesine rağmen doğru bir vasıl yapılamamış, kelime öbeklerinin ve kelimelerin anlamı diğerine atfedilir ve eklenir olmadığından doğru bağlama gerçekleştirilememiştir. Bu cümlelerde kendisine bir şey bağlanılan ve bağlanan unsurlar arasında kabul edilebilir bir münasebet yoktur. Bu itibarla I. Cümlenin:

"Ev sahibi, Yusuf'u akşama kadar güçlükle zapt etti. Yusuf Edremit'e ertesi gün gitmeye razı oldu. (Sabahattin Ali Kuyucakh Yusuf)" biçiminde fasıl yapılarak ve kesik ve ayrık cümleli olarak yazılması gerekir.

"Ne de olsa Edremit'in yerlisiydi ve ailesinin itibarını düşünürdü(Sabahattin Ali Kuyucaklı Yusuf)” 
cümlesinde ise, Yusuf ortak özne olmakla birlikte cümlelerin birisi isim cümlesi, diğeri fiil cümlesi olduğu için birbirine bağlanması uygun düşmemiştir. Aynı şekilde cümlelerin "Edremit'in yerlisi olmak" ve "ailesinin itibartna düşkün olmak" "anlam birimcik demeti (semem)"leri ile "anlam birimcik (sem)”leri arasında bağlanmayı geçerli kılacak bir münasebet yoktur ve bağlanmaları doğru değildir.

Türkiye Türkçesinin Tarihi gramerini meydana getirmek için belirli devreler, şahıslar ve eserlerin dili üzerinde araştırmalar yapılması ve monografiler hazırlanması şarttır. (Eski Türkiye Türkçesi, Faruk Kadri Timurtaş)”

cümlesinde ise bağlanan unsurlar

I-“belirli devreler üzerinde araştırmalar yapılması ve monografiler hazırlanması şarttır.”,

II-“belirli şahıslar üzerinde araştırmalar yapılması ve monografiler hazırlanması şarttır.” ve

III-“belirli eserlerin dili üzerinde araştırmalar yapılması ve monografiler hazırlanması şarttır.”

biçiminde birbirine denk ve eşlenik görünmekle birlikte bağlanan yapılarda en son bağlayıcı olarak kullanılan "ve"den sonraki kısım (iyelik grubunun isim+iyelik unsuru) her üç isim için "dili" ismi ile ortak bir "anlam birimcik demeti (semem)" oluşturamamış ve belirli devreler (in dili), belirli şahıslar(ın dili) ve belirli eserlerin dili biçiminde aynı tamlananda birleşemeyen birbirinden ayrık ve kopuk cümleleri bağlanmış gibi göstermiştir. Birbirini izleyen dizimsel bu cümleler dilbilgisel bakımdan geçerli, fakat anlam bakımından geçersiz "müstakim kezib” cümle özelliği taşır. Cümle içerisinde anlam açısından "eserlerin dili" gibi bir yapı oluşturulması mümkün olmakla birlikte "belirli devrelerin dili" gibi bir yapı oluşturulması mümkün değildir. Sözle kastedilen de zaten bu değildir. Sözle kastedilen "devrelerin ve şahısların dili" değil, "devreler ve şahıslar hakkında veya üzerine"dir. Dolayısıyla bu yapılanmada ortak yönleri aynı olan ve aynı "anlam birimcik demeti (semem)"nde birleşen cümleler değil, ortak yönleri aynı olmayan ve "anlam birimcik (sem)"lerinde ortaklık bulunmayan cümleler birleştirilmeye çalışılmıştır. Cümle bağlama, ayırma ve birleştirmenin sahih olması ve doğru kullanımın gerçekleştirilmesi için anlam açısından ortak bir paydaya sahip kendi içinde benzerlikler gösteren sözlüksel birimlerin aynı hükme bağlanması (iştirak) ve aynı "anlam birimcik demeti (semem)" ile "anklav" oluşturması gerekir.

\section{2.c Kısa-uzun karışık cümlelerle anlatım-(Birleştirme: Sebkimürekkep)}

Kısa-uzun karışık cümlelerle anlatım ayrı yazılabilecek şekilde düzenlenmiş cümleler ile bağlı ve zincirlemeli müselsel cümlelerin bir araya getirilmesinden oluşan anlatımdır. Bir kısmı sebkimevsul ve diğer kısmı sebkimefsulden ibaret olan ve karışık bağlanan bu tür cümleler, belagat semantiğinde uzun cümlelerde tercih edilen ve üstün tutulan bir yöntemdir. Bu yöntem, meani (semantik-anlam bilimi) ile ilgili kitaplarda hem kısa, hem uzun cümleleri birbirine bağlamada kullanılır. Sebkimürekkep, ibarenin kapsadığı ve içerdiği cümle ve (tümleçler)lerden bazısını vasıl (birleştirme-bağlama)ve bazısını da fasıl (uzaklaştırma-ayırma) yaparak toplar, kuralına uygun olarak birleştirir, bağlar ve açılayarak kullanıma hazırlar (Bilgegil, 1989: 109). Bu açıdan kısa-uzun karışık cümlelerle anlatımda anlam her sözcüğün ana dili konuşucusunda uyandırdığı duygu değerine bağlı olarak çok yönlülük ve kapsayıcılık gösterir. Buna bağlı olarak bağdaştırma gramerde olduğu kadar belagat semantiğinde de önemli ve birleştirici bir değer olarak ortaya çlkar. Bu ameliyede kuvvei müfekkire (fikir verme, oluşturma gücü) ile zihinde olanlar toplanır ve "tekarün fi'l hayal" ile onu tamamlayan ve bütünleyen başka şeylerin hatıra getirilmesi sağlanır; o şeyin vasfı ve durumu onu mülahaza edenin hayalinde ayırıcı ve bütünleyici yönleri ile canlandırlır (Karataş, 2016: 309, 311 ). 
Akli ve vehmi (gelecekle ilgili zan ve tahmin) olan şeyleri zihninde toplama, bir araya getirme, hayali olanları kavrama herkesin akıl yürütme gücü, anlama yetisi ve idraki bakımından muhtelif; özdeşlik, çelişmezlik, üçüncü halin imkansızlığı ve yeterli neden gibi düşünmenin temel ilkeleri bakımından değişkenlik gösterir. "Düşünce ağacı kesti”, "ekmeği içtim” gibi cümleler söz dizimi açısından doğru olsa da anlam bilimsel açıdan yanlıştır (Palmer, 2001: 120). Değiştirimle birbirinin yerini alabilen dizisel ve birbirini izleyen dizimsel bu cümlelerde bağdaşıklık hatası (el-istikâme minel-kelam vel-ihâle) oluşturan ve dilbilgisel bakımdan geçerli "müstakim hasen", fakat anlam bakımından geçersiz "müstakim kezib" cümle özelliği söz konusudur. "Müstakim hasen"in gerçekleşmesi için ögelerinin tam olması, kelimelerin sözlük anlamarında kullanılması ve ögelerle anlam arasında tam bir denklik ve eşleniklik bulunması koşuldur (Yıldız, 2012:125). Yapı bakımından doğru, semantik bakımından yanlış olan bu cümleler mecaza bağlanarak veya yorumlanarak bile ele alınsa yapı-anlam bakımından birbiriyle uyumlu olmayan, diğer bir ifadeyle doğruluk değeri ya da mantıksal değeri bir olmayan cümleler olarak sayılır. Batı dil bilimindeki parataxis (yanaşık sıralam)leri andıran ve iki cümlenin veya (kelamda) iki önermenin benzerlik yönü gözetilmeden veya bağlama yönü kullanılmadan art arda sıralanması biçiminde gerçekleşen bu türlü söz dizimsel yapılar (Vardar, 2002: 216) çoğunlukla "anlamsal yerdeşlik", "yerdeşlik ilişkileri” ve "önerme bütünleri” (Toklu, 2007: 139) dikkate alınmadan oluşturulmuş yapılar olarak kabul edilir.

"Fazla acıkmış insanlar gibi ne verirlerse bakmadan yutuyor, memnun oluyordu. (Kızılcık Dalları, Reşat Nuri Gün tekin)”

cümlesi mantıksal ve doğruluk değeri bir olan cümle değildir. Bütün cümlenin fraktal parça cümle boyutu (memnun ol- yüklemli cümle) ile kendine benzerlik boyutu (yut-, memnun ol- yüklemli cümleler) farklıdır. Cümleler arasında kapsayıcı yön ve birleştirme yönü bulunmamakta, cümleler aynı ortak yönde (ciheti camia) birleşmemekte ve "anlam halkası" oluşturamamaktadır.

Mantıksal ve doğruluk değeri bir olan yapı ve anlam yönünden "müstakim hasen" olarak kabul edilen aşağıdaki cümleler ise bağlayıcılar ekseninde doğru oluşturulmuş,

I-“Ben kendimi ve Nilüfer’i bu adamın merhametinden kurtarmalıyım.” Matmazel Noraliyanın Koltuğu, Peyami Safa)”

II-“Kimler eğlendi, kimler avundu? Vecd ve cuşiş kimde idi? Hani mutrip nerede, canan ne oldu? (Erenlerin Bağından Yakup Kadri Karaosmanoğlu)”

fraktal parça cümle boyutu ile kendine benzerlik boyutu aynı olan cümlelerdir. Cümleler arasında hem anlamsal ve hem yapısal bağ ve uyum vardır. Cümlelerin "anlam halkaları" tamamlanmıştır. II. cümle aynı zamanda cümle zincirinde birbirini izleyen dizimli ve ögeleri ardışıklık oluşturan böylece anlam ögeleri arasında kemali ittisal bulunan çizgisel özellikli cümledir.

"Büyük üstadım Gourmond şunu der: Bütün canlı mahlukata nazaran insanın faikiyetini yapan,
istidatlarının tenevvüüdür. En zeki hayvan bir tek şey yapar. (,veya ;) (f)Fakat onu mükemmel
yapar: (.) At, arka ayaklarıyla, Dempsey ve Carpantier'nin yumruklarından daha mükemmel çifteler
atar; (.) (A)arı, kimyahane firınlarına ve dolaşı imbiklere hiç muhtaç olmaksızın bir Berthelot
dehasıyla balını süzer, (.) (Ö)örümcek, en usta bir dokumacı gibi havai tuzağının namer'i tellerini
örer. Fakat o kadar! Halbuki binbir sahaya dağılmış çalışan insan faaliyetinin mahsulleri, bizzarure
nakıs ve muvakkattır. Hayvan, gayesine varmış duruyor, insan gayesini hala aramakla meşguldür.
(Bize Göre, Ahmet Haşim)"

Türkçe belagat semantiğinde cümle birleştirmeye - karışık bağlama'ya- (seki mevsul)'a örnek, yukarıdaki cümleden büyük dil birliğinde ise, birbirinden bağımsız ve müstakil, anlamca birbiriyle ilgili bağımlı ve bağımsız ve birbirine bağlı ve zincirlemeli (müselsel) cümleler bir bütün oluşturmak üzere 
dizimsel eksen üzerinde çizgisel biçimde sıralanmıştır. Ancak metnin "anlam halkaları"nı oluşturan cümleler doğru ayrımlanmamış, fasıl ve vasıllar doğru yapılmamıştır. Bu bütünde yer alan her bir cümlenin ve cümleden büyük dil birliğinin öbürlerine bağımlı olduğu ve "anlam halkası" oluşturmak üzere dizilendiği bu sebeple bütün olarak ele alınması; ancak anlamı tamamlayıp graf (çizge) ve ana cümle ile aynı özellikleri gösteren "anklav"lı yapı oluşturamadığı için ayrı yazılması gerekir. Bu durumda “anlam halkaları”nı oluşturmak üzere dizilenmiş “,” ve “; gibi bağlayıcı işaretlerle bağlanmış cümle ve cümleden büyük dil birliklerinin "söz dizimsel bileşen"lerine göre doğru ayrımlanması ve parantez içindeki biçimlerde yazılarak metinsel tutarılığın sağlanması ve bütünsel anlamın tamamlanması icap eder.

Kısa-uzun karışık cümlelerle anlatımda cümlenin yapısı ile anlamı arasında meani ilmi çerçevesinde derin ve zengin ifade yaratmak üzere işlevsel ve anlamsal ilişki kurulur. Cümlede belirtilen yargıyla değil, sözü üreten konuşmacıyla ilgili olan cümleden büyük dil birlikleri, cümlenin ifade ettiği yargıda herhangi bir değişiklik yapmaz sadece konuşucunun yargı hakkındaki tutum ve düşüncelerini gösterir. Cümlenin diğer cümlelerle ve cümleden büyük dil birlikleri ile nasıl irtibatlandırıldığını gösteren ve gösterdiği ilişkinin çeşidine göre cümleler arasında bazen kalıcı, bazen geçici ilişki sağlayan bağlayıcılar, cümlede belirtilen yargının konuşmacı tarafından nasıl karşılandığını ve yorumlandığını ortaya koyar (Daşdemir, 2014: 141). Bu cümlelerde bağlayıcı olarak “,” ve “;” gibi işaretler kullanılır. Türkçede sıklıkla kullanılan ve az ögeli olan bu tarz cümlelerde birbirini yapıca ve anlamca tamamlama ilişkisi sezilir.

\begin{abstract}
"Ben her şeyi yaparım, herbir işi irtikap ederim ama, bu işi yapamam. Acımdan şuracıkta can versem, ıssız köye girip de yemeğini yiyemem. Ve acımdan ölüyorum. Ayakta duramıyorum. (Dağın Öte Yüzü, Yaşar Kemal)"
\end{abstract}

cümlesi fasıl yapılmış, fakat "ve" bağlayıcısı ile başlatılarak "vasıl” varmış gibi kullanılmıştır. "Ve" bağlayıcılı cümle vaslın koşullarını sağlıyor ve vasıl yapılıyorsa "ve"den önce gelen cümle ile "ve"li cümlenin bir tek cümle halinde ve bağlı cümle olarak kullanılması gerekir. Bu itibarla birinci cümlenin anlamıyla ikinci cümlenin anlamının bütünlük arz etmediği ve aralarında kapsayıcı yön ve birleştirme yönü (ciheti camia)' nün olmadığı ve tam bir ilgi (Kemali ittisâl) bulunmadığı bu cümlelerin bağlanmaları doğru değildir. Cümlelerin her şeyden önce ortak "anlam birimcik(sem)"ler aracılı̆̆ıyla anlamsal kesişim kümesi ve arakesiti oluşturması, aynı şekilde cümleler arasında manaca alaka ve münasebet bulunması, II. cümle I. cümlenin açıklayıcısı ve sebebi olduğunda bir tek cümle biçiminde düzenlenmesi gerekir. Aynı şekilde ardışık olarak sıralanmış bu oluşumlarda cümlelerin özneleriyle yüklemleri arasında mukayese yönü olması ve münasebet bulunması böylece cümlelerin yahut cümleden büyük dil birliklerinin anlam bütünlüğünü sağlayan "anlam bilimsel yerdeşlik"in" sağlanmış olması zorunludur.

\title{
3. Sonuç
}

Yazılı ve Sözlü anlatımda bedii ve estetiki ifadeler kullanmak, tam ve bütün fikri ortaya koymak üzere fasih ve beliğ cümleler kurmak dil kullanıcısının sağlam ve doğru anlatımla gerçekleştirmeye çalıştığı bir icad "var etme" ve ibda "oluşturma" ameliyesidir. Belagat semantiğinde cümle bağlama ayırma ve birleştirme kılgısı ile ilgili bu husus, cümlelerin birbiriyle uyumu ve uygunluğu gözetilerek ve cümle oluşturmanın şartları yerine getirilerek diğer bir ifade ile anlamın tamamlanıp tamamlanmadığına ve cümlelerin graf (çizge) oluşturup oluşturmadıklarına bakılarak belirlenir. Klasik Doğu dil öğretiminde nahiv ve belagat ve Batı literatüründeki dil bilim ve retoriği ilgilendiren " cümle bağlama, ayırma ve birleştirme”, cümle ve üslup bilgisi işletilerek ve bağlayıcılar doğru ve kuralına uygun kullanılarak gerçekleştirilir. Bu bağlamda bağlayıcıların doğru ve yerinde kullanılması cümlelerin hem fraktal (parça 
cümle) boyutunun ve hem kendine benzerlik (bütün cümle) boyutunun denk ve eşlenik olmasını ve "anlam halkaları" oluşturarak tam ve bütün fikrin ortaya çıkmasını sağlar.

Osmanlı belagat semantiğinde yoğunluklu olarak işlenen ve cümlelerin dağılımını ve bireşimini sağlayan cümle bağlama, ayırma, birleştirme, Türk cümlesinin uzun soluklu serüveni içinde Arap belagatinin ve nahvinin etkisinde ortaya çıkmış; ağırlıklı olarak Arapça kökenli "ve" bağlayıcısının merkezinde tekasüf ve tekamül etmiştir. "Ve" bağlayıcısı ortak paydada birleşen "anlam birimcik (sem)" ve "anlam birimcik demeti (semem)"lerin oluşturduğu cümleler kümesi "anlam halkaları"nın ve ana cümle ile benzer düzenleniş özelliği gösteren cümleler kesiti "anklav"l cümlelerin oluşmasında etkin rol oynar. Cümleleri bağlama, ayırma ve birleştirmede belirleyici ve ayrımlayıcı işlev görür, bu itibarla "ve" bağlayıcısını doğru ve yerinde kullanmak Arap ve Osmanlı semantiğinde belagatin temeli olarak kabul edilmiş ve çok önemsenmiştir.

Türkçenin bugünkü cümle yapısında bağlı ve sıralı bağlı cümlelere denk düşen ve "ve” bağlacı, “,” ,"; noktalı virgül ve bă̆ fiil eki "(y)Xp” nin dahliyle kurulan bu yapılar, oluşturulmalarında tam bir denklik ve eşleniklik; kullanımlarında büyük bir dikkat ve rikkat gerektirir. Başlıca sıralama edatı durumundaki "ve" bu ameliyede esas bağlayıcı olarak ve yoğun biçimde kullanılır. Arka arkaya gelen cümleleri bir araya getirir, "ve" manası ile ve virgül makamında birbirine bağlar. Bağladığı iki unsurun arasına girer ve unsurlar arasında yer değiştirmeyi (tertip) ve eşit şartlarda kullanılmayı sağlar ve söz dizimsel ve anlam bilimsel bir konfigürasyon gerçekleştirir. Böylece kendisine bağlanılan önceki ve bağlanan sonraki yapıların yapı ve anlam yönünden mutabakatını ve aynı hükme ortaklığını tayin ve terfi eder.

Bununla birlikte Türkçede "ve” bağlayıcısı ve denkliğindeki “,” ve “;” kural çıkarma yerine kural koyma kodifikasyonu ile kullanıldığından "ve" kullanımlarında bağlayıcılık değerlerinde tutarlılık ve ölçünlük gözetilmediğinden "ve” bağlacı ve "ve” bağlacı karşllğında kullanılan “,” ve “;”ün bağh ve sırah cümleler dahil bağlandıkları her yapıda ve söz dizimsel bileşende doğru bağdaştırmalar yaptıkları ve cümlelerin "anlam halkaları"na uygun bir kullanım sağladıkları söylenemez. Bu bakımdan "ve” bağlayıcısı ekseninde oluşan birçok cümlenin hem imla bakımından hem sentaktik ve semantik bakımdan ikircikli ve çelişikli; belagat ve retorik noktainazarından kusurlu olduğu görülür. Ve bağlayıcısının kullanımında kapsayıcı yön ve birleştirme yönü (=ciheti camia)ne dikkat edilmemesi bağlanan unsurlar arasında tam bir ilgi (kemali ittisâl) ve birleşme (ittihat) ile hükümde ortaklık ve anlamda bütünlük gözetilmemesi "ve" bağlayıcısının kullanımındaki temel kusurlardandır. Aynı şekilde noktalama işaretlerinin belagat semantiğindeki sebkimevsul, sebkimefsul ve sebkimürekkep (cümle bağlama, ayırma, birleştirme) konularına eşlenik karşılıklarla değil, genel kabullerle ve durağan biçimleriyle öğretilmesi ve aynı metnin dil kullanıcıları tarafından farklı biçimlerde ve farklı noktalama işaretleri ile işaretlenmesi bağlayıcılar ekseninde ortaya çıkan diğer kusurlardandır. Bu kusur (yanlışlık ve tutarsızlık)ların doğmasında cümlenin durağan yönünün dikkate alınması, devingen yönünün dikkate alınmaması, diğer bir ifadeyle cümlenin taşıdığı anlam yükünün çoğu kez ihmal edilmesi ve anlam içeriğinin bağlamdan çlkarılamaması etkin rol oynar.

Bağlayıcı olarak "ve” bağlacının ve “,” ve “;” gibi bağlama işaretlerinin yerinde ve doğru kullanılabilmesi için belagat semantiğinde cümlelerin sebkimevsul, sebkimefsul ve sebkimürekkep konularına uygun bir içerik; bağlayıcıların açık-örtük, doğrudan-dolaylı bileşenlerinin dağılımına uygun içerim taşıması; tam ve mütemmim cümlelerin, düşünce, duygu ve imgelerin kodifikasyonuna göre dizimlenmiş ve bağlayıcılar vasıtasıyla ayırma (fasıl), bağlama (vasıl) ve hem ayırma ve bağlama (fasıl ve vasıl) yapılarak hükme rabt edilmiş olması gerekir. 


\section{Kaynakça}

Akçataş, A. (2007). Türkiye Türkçesinde Yapı, İşlev Ve Anlam İlişkileri Açısından Cümle Grupları Ve Cümle Türleri Üzerine Bir Deneme. Belleten 2007/I, s.7-19.

Aksan, D. (1995). Her Yönüyle Dil (Ana Çizgileriyle Dil bilim1). İstanbul: Levent Ofset Mat. ve Yayıncillk.

Araz, M. F. (2016). Yorum Farkhlhğına Etkisi Bakımından Kur'an'daki Zamirlerin Mercii (Bakara Suresi Örneklemesi). Isparta: Süleyman Demirel Üniversitesi Sosyal Bilimler Enstitüsü Yüksek Lisans Tezi.

Bilgegil, K. (1989). Edebiyat Bilgi ve Teorileri. İstanbul: Enderun Kitabevi, 2. baskı.

Dağ, P \& Gümüș, İ. (2018). Delalet ve Gösterge Kavramlarının Belagat-Göstergebilim İlişkisi Bağlamında Değerlendirilmesi. Littera Turca Journal of Turkish Language and Literature, 4, 649-659.

Daşdemir, M. ( 2014). Oklama Yöntemiyle Türkçenin Yapısal-İşlevsel Söz Dizimi. Erzurum: Eser Basım Yayın Dağıtım Matbaacılık.

Daşkıran, Y. (2018). Arap Dilinde Bağdaşıklık. Dinbilimleri Akademik Araştırma Dergisi. Cilt 18, Sayı 2, 2018 S-399-419.

Demirci, F. (2017). Arap Belagatinde Fasıl Vasıl Meselesi Ve Kur'an Nazmı Üzerindeki Yansımaları (Ali İmran Suresi Örnekliğinde). İstanbul: İstanbul Üniversitesi Sosyal Bilimler Enstitüsü Yüksek Lisans Tezi.

Durmuş, İ. (2000). İnşâ Maddesi. Diyanet İslam Ansiklopedisi, C. 20, s. 334-337.

Durmuş, İ. (2012). Fasıl Maddesi. Diyanet İslam Ansiklopedisi, C. 12, s. 206.

Durmuş, İ. (2012-2). Vasıl Maddesi. Diyanet İslam Ansiklopedisi, C. 42, s. 537-539.

Ertuğrul, O. (2015). Belagatta Meani ilmi. Iğdır Üniversitesi İlahiyat Fakültesi Dergisi, Nisan-April 2015, S.5, s.155-180.

Filizok, R. \& Akdeniz, S. (2019). Belagat Bilimimizin İçerdiği Teoriler: Güzel Söz Teorisi, http://www.ege-edebiyat.org/docs/512.pdf (erişim tarihi. 11.11.2019).

Gökçe, H. (2006). Miyarul Kelam-Selim Sabit (Metin-İnceleme-Sözlük). Yayımlanmamış Yüksek Lisans Tezi. İstanbul: Marmara Üniversitesi Türkiyat Araştırmaları Enstitüsü Türk Dili ve Edebiyatı Anabilim Dalı.

Güneş, S. (1999). Anlatım Bilgisi. İzmir: Dokuz Eylül Üniversitesi Basımevi, 2. Baskı.

Hacibekiroğlu, A. (2015). Arap Dilinde Edatların Metinde Kurduğu Anlamsal İlişkiler. Yayımlanmamış Doktora Tezi. Ankara: Yıldırım Beyazıt Üniversitesi Sosyal Bilimler Enstitüsü.

Karabey, T. \& Atalay, M. (2000). Belagat-ı Osmâniye- Ahmet Cevdet Paşa. Erzurum

Karataş, A. (2016). Raşid’in Külliyat-ı Kavaidi Lisani Osmani Adlı Eserinin Metin Çevirisi Ve Incelemesi. Denizli: Pamukkale Üniversitesi Eğitim Bilimleri Enstitüsü Türkçe Eğitimi Anabilim Dalı Yüksek Lisans Tezi.

Kerimoğlu, C. (2017). Kuram ve Uygulamalarla Dil bilim Göstergebilim ve Türkoloji-Genel Dil bilime Giriş. Ankara: Pegem.

Kıran, Z. (1999). Sözceleme ve Göstergebilim. Dil bilim Araştırmaları, s. 93-99.

Kızılkaya, Y. (2019). Belagatin Fasıl ve Vasıl Konusuna Türkçe Kavramsal Çerçeveden Bir Bakış: Siralı Bağlı Cümleler. Tasavvur Tekirdağ İlahiyat Dergisi , c. 5, s. 2: 1367-1392.

Nazima, A. (1329). Lisân-ı Osmânî İkinci Senesi Sarfve Nahiv Kısmı. İstanbul: Tefeyyüz Kütüphanesi.

Özdoğan, M. A. (2012). Arap Belağatinde Fasl ve Vasl Olgusu. KSÜ İlahiyat Fakültesi Dergisi. C. 19, s 41-74. 
Palmer, F. R. (2001). Semantik-Yeni Bir Anlambilim Projesi. Ankara: Kitabiyat.

Sami, Ş. ( 1887). Usûli Tenkit ve Tertip. İstanbul: Mihran.

Sevinç, R. (2017). Belâğatta Fasıl-Vaslın Genel Kuralları Ve "Vâv"In Kullanımı. Ekev Akademi Dergisi, Yll: 21 Sayl: 69, S. 53-88.

Stebleva, İ. V. (1965). Poeziya Tyurkov. Moskova: YI-YIII Vekov.

Şimşek, Ş. (2018). Arap Gramerinde Terim Sorunu: Cümle-Kelam Örneği. BüİFD, Sayı: 12 | Yıl: 2018/2, s. 273-300.

Toklu, O. (2007). Dil bilime Giriş. Ankara: Akçă̆.

Ülgen, E. (2015). Arap Belağatının Özgünlüğü İle İlgili İddialar Ve Bunların Değerlendirilmesi. Uluslararası Sosyal Araştırmalar Dergisi, C.8, S.41, s. 1386-1393

Üstünova, K. (1998). Dede Korkut Destanları Ve Cümleden Büyük Birlikler. İstanbul: Alfa.

Üstünova, K. (2001). Cümleden Büyük Birlikler. Türk Dili Dil ve Edebiyat Dergisi. S.6oo, s.786-797, Ankara: TDK Yayınları

Vardar, B. (2002). Dil bilim Terimleri Sözlüğü. İstanbul: Multilingual.

Yetiş, K.. (1992), Belagat. Diyanet İslam Ansiklopedisi C.5, s.384-387.

Yetiş, K. (1996). Talîmi Edebiyât’ın Retorik Ve Edebiyat Nazariyâtı Sahasına Getirdiği Yenilikler. Ankara: Atatürk Kültür Merkezi Yayını, Xxv+685.

Yıldız, M. (2012). Modern Dil bilim Ekseninde Klasik Arap Filolojisinde Dilin İşleyişi Sorunu. Ondokuz Mayıs Üniversitesi İlahiyat Fakültesi Dergisi, S. 32, s. 111-128.

Yılmaz Orak, K. (2013). Belagat Geleneğimiz ve Belagat-i Lisân-ı Osmanî. İstanbul: Kitabevi. 